http://jmscr.igmpublication.org/home/ ISSN (e)-2347-176x ISSN (p) 2455-0450 crossref DOI: https://dx.doi.org/10.18535/jmscr/v8i10.37

\title{
Neurological Manifestations of COVID 19 - Case Series
}

\author{
Authors
}

\section{Dr Harshal Bhitkar ${ }^{1}$, Dr Sanjay Mundhe ${ }^{2}$, Dr Nagnath Redewad ${ }^{3}$, Dr Neha Suryavanshi ${ }^{4}$, Dr R.T. Borse ${ }^{5}$, Dr Priyanka Walzade ${ }^{6}$, Dr Mayank Choudhary ${ }^{7}$, Dr S. A. Sangle ${ }^{8}$ \\ ${ }^{1,2,3}$ Associate Professor, Dept of Medicine, BJGMC Pune \\ ${ }^{4,6}$ Assistant Professor, Dept of Medicine, BJGMC Pune \\ ${ }^{5}$ Professor, Dept of Medicine, BJGMC Pune \\ ${ }^{7}$ Junior Resident, Dept of Medicine, BJGMC Pune \\ ${ }^{8}$ Professor \& HOD, Dept Of Medicine, BJGMC Pune \\ Corresponding Author \\ Dr Sanjay Mundhe}

\section{Introduction}

Coronavirus disease (COVID-19) a disease caused by the novel virus (SARS-CoV-2) has become a global pandemic threat. Starting from Wuhan, China in December 2019, it has now spread across the world affecting 32.7 millian people \& 9,92,000 deceased till September. SARS-CoV-2 is primarily transmitted between people through respiratory droplets. It can bind to the angiotensinconverting enzyme 2 (ACE2) receptor in the lungs. After which most people (80\%) are asymptomatic or develop mild symptoms, such as coughing or fever. ${ }^{1}$ However, the disease can lead to more severe problems such as moderate to severe respiratory disease and some of them develop systemic complications like acute kidney injury, hepatitis, myocarditis, and disseminated coagulopathy. ${ }^{2,3}$ As the experience with the disease is increasing, neurological manifestations are being reported increasingly. ${ }^{4,5}$ We hereby describe three patients affected with COVID 19 who developed neurological manifestation in the form of neuropathy.

\section{Case 1}

A 31 year old male, plumber by occupation, presented with complaints of 2- 3 loose stool per day, diffuse abdominal pain and breathlessness since 2-3days. There was no history fever, cough, chest pain, palpitations. No contact history with COVID positive patient. On general examination, patient was afebrile, pulse 90/min, BP 104/60 $\mathrm{mmHg}$, SPO2 $91 \%$ on room air, patient also had periorbital swelling, facial puffiness, bilateral pedal edema. Patients chest x-ray showed bilateral reticular shadows scattered all over the lung fields. Patient was tested for SARS CoV2 by CBNAAT and found positive. His laboratory investigations were s/o acute kidney injury with normal size kidneys on USG Abdomen .(Sr. Creatinine - 6.1, BUN- 261)Patient was kept on nasal $\mathrm{O} 2$ support in COVID isolation ward and started on appropriate treatment which included Antibiotics, Methylprednisolone, Heparin, Vit C $\&$ Zinc. During his stay on $8^{\text {th }}$ day, patient noticed bilateral lower limb weakness. 
On neurological examination, he was conscious and oriented; Cranial nerve examination was normal, On Motor examination, bilateral lower limb distal muscles were hypotonic, power was $2 / 5$ in right lower limb, 4/5 in left lower limb, with bilateral knee \& ankle reflex were absent with bilateral flexor plantar response. Upper limb motor examination was normal. Sensory examination revealed no abnormality and bowel and bladder functions were normal. His Nerve conduction studies were suggestive of sensory motor axonal polyneuropathy affecting both lower limbs. On 20 th day of admission, CSF \& Serum analysis showed presence of both IgG (positive) \& IgM (weakly positive) antibodies for COVID 19. Patient received treatment in the form of Plasma exchange 5 cycles. Over a period of 25 days patient showed clinical improvement and had 4/5 power in both lower limb on discharge. His renal function also improved with normal serum creatinine and was advised to follow up.

\section{Case 2}

A 61 year old male presented with complaints of shooting pain from hip to heel followed by sudden onset, bilateral lower limb symmetrical weakness, proximal followed by distal, which progressed for 24 to 36 hours. It was associated with loss of crude touch and pain sensation in bilateral lower limb and normal bowel and bladder function. Patient also gave history of low grade fever\& dry cough since 2 days. No h/o Dyspnea, recent vaccination, trauma, vomiting or loose stools.

On General examination, pulse was 92/minute and $\mathrm{SPO} 2$ was $94 \%$ on room air. On Initial neurological examination, higher functions and cranial nerve examination was normal. On motor examination he had zero power in both lower limb with bilateral absent knee and ankle reflex and mute plantar response. Upper limb motor examination was normal. Neck holding was good. $\mathrm{X}$ ray chest was s/o bilateral peripheral lung infiltrates. HRCT chest revealed ground glass opacities in bilateral lower zone. He was found to be positive for COVID 19 (CBNAAT) and was admitted in isolation ward.

Patient underwent NCV studies which showed absent $\mathrm{F}$ waves in both tibial and right peroneal nerve and prolonged $F$ waves in left ulnar and left peroneal nerve, which was consistent with Guillian Barre syndrome. CT spine was suggestive of cervical spine degenerative changes. Other biochemical parameters were normal. CSF examination showed albuminocytological dissociation (Total cell -9, Proteins- $88 \mathrm{mg} / \mathrm{dl}$, sugar $-42 \mathrm{mg} / \mathrm{dl}$ ) \& presence of Ig $\mathrm{G}$ antibodies for COVID 19. Patient received Antibiotics, Methylprednisolone, Clexane, Favipiravir, Vit C, Zinc \& calcium supplements. He also underwent 5 cycles of plasma exchange on alternate day. He improved gradually over period of 20 days with $4 / 5$ in right lower limb and 5/5 in left lower limb. He was discharged on $22^{\text {nd }}$ day and adviced follow up.

\section{Case 3}

A 65 year old female presented with c/o fever, caught and breathlessness since 5 days. Patient was febrile, pulse 98/min, BP-110/70 mmHg, SPO2-92 on Room air. X-ray chest s/o Bilateral peripheral infilterats. Patient was tested for SARS COV-2 by CIBINAAT and found positive. Patient was kept on Nasal Oxygen support in COVID isolation ward. Patient received treatment in the form of antibiotics, Dexa, clexane, HCQS, Vit C, Zinc. During her stay she noticed difficulty in walking on $10^{\text {th }}$ Day.

On neurological examination she was conscious and oriented, cranial nerve examination was normal, on motor examination patient had weakness in all four limbs, more in lower limbs than upper limbs. Power was $2 / 5$ in both lower limb and 4/5 in both upper limbs. Reflexes were diminished in all four limbs. Sensory and bowlbladder were normal.

With this clinical background Nerve conduction study was done s/o Axonal Sensory Motor Polyneuropathy affecting all four Limbs. CSF examination suggestive of Albumino-cytological 


\section{JMSCR Vol||08||Issue||10||Page 240-245||October}

dissociation $($ Total Cells $=0$, Proteins $=70 \mathrm{mg} / \mathrm{dl}$, Sugar $=40 \mathrm{mg} / \mathrm{dl}$ ) with RTPCR COVID positive and COVID IgM/IgG antibodies negative. Patient was started on plasmapheresis and received 6 cycles over a period of 12 days. Patient had significant improvement in power, $4 / 5$ in bilateral lower limbs and normal in both upper limbs. Patient was able to walk independently on $14^{\text {th }}$ day of treatment. Patient was discharged and was advised follow up.

\section{Sensory Nerve Studies UPPER LIMB}

\begin{tabular}{|c|c|c|c|c|c|}
\hline \multicolumn{5}{|c|}{ Nerve: Rlght Median Wrist } & \\
\hline sita & (ms) & (ms) & Amp & $\frac{(\mathrm{m} / \mathrm{s})}{49.13}$ & \\
\hline \multirow{2}{*}{\multicolumn{6}{|c|}{\begin{tabular}{|c|c|} 
Wrist & 3.46 \\
Nerve: Left Median Wrist \\
\end{tabular}}} \\
\hline & & & & & \\
\hline Site & $\begin{array}{c}\text { Iat1 } \\
\text { (ms) }\end{array}$ & $\begin{array}{l}\text { Dur } \\
\text { (ms) }\end{array}$ & Anp & $\begin{array}{l}\text { NCV } \\
(\mathrm{m} / \mathrm{s})\end{array}$ & $2 \mathrm{mS} 20 \mu \mathrm{V}$ \\
\hline Wrist & 2.96 & 1.00 & $19.5 \mu \mathrm{V}$ & 57.43 & \\
\hline \multicolumn{6}{|c|}{\begin{tabular}{|l|l} 
Nerve: Right Ulnar Wrist \\
\end{tabular}} \\
\hline Site & $\begin{array}{l}\text { Iat1 } \\
\text { (ms) }\end{array}$ & $\begin{array}{l}\text { Dur } \\
\text { (ms) }\end{array}$ & Amp & $\begin{array}{l}\text { NCV } \\
(m / s)\end{array}$ & $2 \mathrm{mS} 20 \mu \mathrm{V}$ \\
\hline Wrist & 2.75 & 2.00 & $36.8 \mu \mathrm{V}$ & 61.82 & \\
\hline \multicolumn{6}{|c|}{ Nerve: Left Ulnar Wrist } \\
\hline Site & \begin{tabular}{|l|} 
Iat 1 \\
(ms) \\
\end{tabular} & $\begin{array}{l}\text { Dur } \\
\text { (ms) }\end{array}$ & Amp & $\begin{array}{l}\text { NCV } \\
(\mathrm{mi} / \mathrm{s})\end{array}$ & $2 \mathrm{mS} 20 \mathrm{NV}$ \\
\hline Wrist & 2.38 & 1.17 & $27.0 \mu \mathrm{V}$ & 21.43 & \\
\hline
\end{tabular}

\section{LOWER LIMB}

Nerve: Right Sural

\begin{tabular}{|c|c|c|c|c|}
\hline Site & $\begin{array}{c}\text { Iat1 } \\
\text { (ms) }\end{array}$ & $\begin{array}{c}\text { Dur } \\
\text { (ms) }\end{array}$ & Amp & NCV \\
(m/s)
\end{tabular}

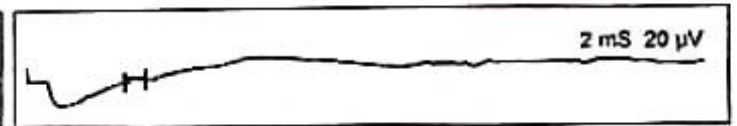

\section{F Wave Studies LOWER LIMB}

Nerve: Left Median

\begin{tabular}{|c|c|c|c|}
\hline M Lat & Fmin Lat & Fmax Lat & Fmean Lat \\
\hline $1.0 \mathrm{~ms}$ & $22.9 \mathrm{~ns}$ & $25.0 \mathrm{~ms}$ & $24.0 \mathrm{nS}$ \\
\hline
\end{tabular}

Nerve: Left Ulnar

\begin{tabular}{|c|c|c|c|}
\hline M Lat & Fmin Lat & Fmax Lat & Fmean Lat \\
\hline $18.8 \mathrm{mS}$ & $22.9 \mathrm{m.5}$ & $31.0 \mathrm{~ms}$ & $27.0 \mathrm{~ms}$ \\
\hline
\end{tabular}

\section{Nerve: Right Median}

\begin{tabular}{|c|c|c|c|}
\hline N Lat & Fmin Lat & Fmax Lat & Fmean Lat \\
\hline $1.0 \mathrm{~ms}$ & $22.9 \mathrm{mS}$ & $25.0 \mathrm{xS}$ & $24.0 \mathrm{~ms}$ \\
\hline
\end{tabular}

\begin{tabular}{|c|c|c|c|}
\hline \multicolumn{4}{|c|}{ Nerve: Right Tibial Nerve } \\
\hline M Lat & Fmin Lat & Fmax Lat & Emean Lat \\
\hline $15.2 \mathrm{mI}$ & $-10.0-\min$ & 32.12 ils- & $31.0-7 \mathrm{ME}$ \\
\hline
\end{tabular}




\section{Motor Nerve Studies \\ UPPER LIMB}

Nerve:Right Median

\begin{tabular}{|c|c|c|c|c|}
\hline Site & $\begin{array}{c}\text { Lat1 } \\
\text { (ms) }\end{array}$ & $\begin{array}{c}\text { Dur } \\
\text { (ms) }\end{array}$ & Amp & $\begin{array}{c}\text { NCV } \\
\text { (m/s) }\end{array}$ \\
\hline Wrist & 3.85 & 11.56 & $5.6 \mathrm{mV}$ & 52.03 \\
\hline Elbow & 10.00 & 13.65 & $3.4 \mathrm{mV}$ & \\
\hline Nerve: Left Median
\end{tabular}

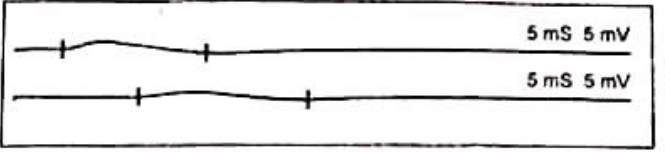

\begin{tabular}{|c|c|c|c|c|}
\hline Site & $\begin{array}{c}\text { Lat1 } \\
\text { (ms) }\end{array}$ & $\begin{array}{c}\text { Dur } \\
\text { (ms) }\end{array}$ & Amp & $\begin{array}{c}\text { NCV } \\
(\mathrm{m} / \mathrm{s})\end{array}$ \\
\hline Wrist & 4.17 & 11.35 & $4.3 \mathrm{mV}$ & 60.50 \\
\hline Elbow & 9.79 & 12.92 & $3.3 \mathrm{mV}$ & \\
\hline
\end{tabular}

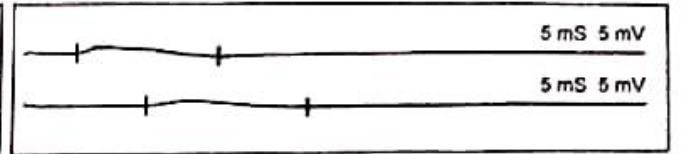

Nerve: Right Uinar

\begin{tabular}{|c|c|c|c|c|}
\hline Site & $\begin{array}{c}\text { Lat1 } \\
\text { (ms) }\end{array}$ & $\begin{array}{c}\text { Dur } \\
\text { (ms) }\end{array}$ & Amp & $\begin{array}{c}\text { NCV } \\
(\mathrm{m} / \mathrm{s})\end{array}$ \\
\hline Wrist & 1.98 & 12.71 & $1.5 \mathrm{mV}$ & 55.66 \\
\hline Elbow & 7.19 & 12.71 & $1.7 \mathrm{mV}$ & \\
\hline
\end{tabular}

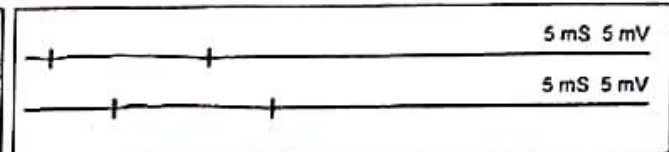

\begin{tabular}{|c|c|c|c|c|}
\hline Nerve: Left Ulnan & $\begin{array}{r}\text { Lat1 } \\
\text { (ms) }\end{array}$ & $\begin{array}{c}\text { Dur } \\
\text { (ms) }\end{array}$ & Amp & $\begin{array}{c}\text { NCV } \\
\text { (m/s) }\end{array}$ \\
\hline Site & 1.25 & 11.67 & $1.4 \mathrm{mV}$ & 58.00 \\
\hline EIbist & 6.25 & 11.67 & $1.6 \mathrm{mV}$ & \\
\hline
\end{tabular}

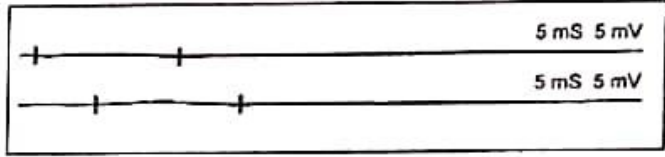

\section{LOWER LIMB}

Nerve: Right Peronea

\begin{tabular}{|c|c|c|c|c|}
\hline Site & $\begin{array}{c}\text { Lat1 } \\
\text { (ms) }\end{array}$ & $\begin{array}{c}\text { Dur } \\
\text { (ms) }\end{array}$ & Amp & $\begin{array}{r}\text { NCV } \\
\text { (m/s) }\end{array}$ \\
\hline Ankle & 7.40 & 10.63 & $0.3 \mathrm{mV}$ & $\mathbf{5 9 . 9 3}$ \\
\hline Knee & 1.56 & 15.73 & $0.5 \mathrm{mV}$ & \\
\hline
\end{tabular}

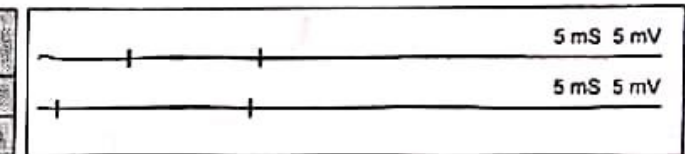

\section{Nerve: Left Peroneal}

\begin{tabular}{|c|c|c|c|c|}
\hline site & $\begin{array}{c}\text { Iat1 } \\
\text { (ms) } \\
\end{array}$ & $\begin{array}{l}\text { Dur } \\
\text { (ms) }\end{array}$ & Amp & $\begin{array}{l}\text { NCV } \\
(\mathrm{m} / \mathrm{s})\end{array}$ \\
\hline Ankle & 1.98 & 13.13 & $0.4 \mathrm{mV}$ & 72.55 \\
\hline Knee & 7.08 & 10.52 & $0.4 \mathrm{mV}$ & 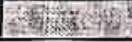 \\
\hline \multicolumn{5}{|c|}{ Nerve: Right Tiblal } \\
\hline Site & $\begin{array}{c}\text { Lat1 } \\
\text { (ms) }\end{array}$ & $\begin{array}{l}\text { Dur } \\
\text { (ms) }\end{array}$ & Amp & $\begin{array}{l}\mathrm{NCV} \\
(\mathrm{m} / \mathrm{s})\end{array}$ \\
\hline Ankle & 4.48 & 12.92 & $0.7 \mathrm{mV}$ & 40.35 \\
\hline Knee & 13.65 & 11.46 & $0.7 \mathrm{mV}$ & 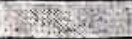 \\
\hline
\end{tabular}

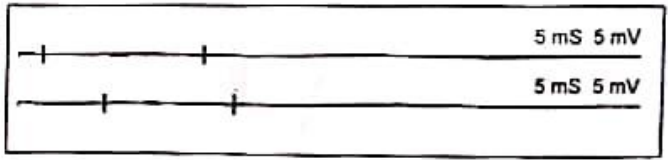

Nerve: Left Tibla

\begin{tabular}{|c|c|c|c|c|}
\hline Site & $\begin{array}{c}\text { Lat1 } \\
\text { (ms) }\end{array}$ & $\begin{array}{c}\text { Dur } \\
\text { (ms) }\end{array}$ & Amp & $\begin{array}{c}\text { NCV } \\
\text { (m/s) }\end{array}$ \\
\hline Ankle & 3.75 & 13.44 & $0.4 \mathrm{mV}$ & 43.33 \\
\hline Knee & 12.29 & 10.31 & $0.9 \mathrm{mV}$ & \\
\hline
\end{tabular}

\begin{tabular}{|rr}
\hline$+1,25 \mathrm{~ms} 5 \mathrm{mv}$ \\
\hline+1
\end{tabular}

NOTE: THE RESULTS SHOULD BE CUINICALLY CORRELATED

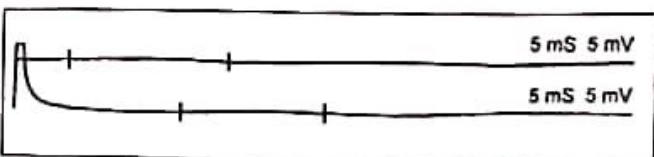

\section{Discussion}

Although the COVID-19 disease predominantly affects respiratory system, there have been case reports and studies highlighting the neurological manifestations seen in some cases. Considering the caseload of affected population, even if the percentage of patients having neurological manifestations is very small, the absolute number of patients with neurological manifestation can be very high.

The potential involvement of COVID-19 in central nervous system (CNS) has attracted considerable attention due to neurological manifestations presented throughout the disease process. In addition, SARS-CoV-2 is structurally similar to SARS-CoV, and both bind to the 
angiotensin-converting enzyme 2 (ACE2) receptor to enter human cells. Thus, cells expressing ACE2, such as neurons and glial cells may act as targets and are thus vulnerable to SARS-CoV-2 infection.

Central nervous system manifestations documented are dizziness, headache, acute cerebrovascular disease, altered consciousness, encephalopathy, acute myelitis and ataxia. Peripheral nervous system manifestations documented include hypogeusia, hyposmia, Guillian Barre syndrome, neuralgia, skeletal muscle injury. ${ }^{6}$ The neurological manifestations could be due to the virus itself, immune mediated injury or a part of systemic complications of severe disease.

SARS-CoV-2 RNA detected in a cerebrospinal fluid specimen of a patient with COVID-19 has provided direct evidence to support the theory of neurotropic involvement of SARS-CoV-2. However, the underlying neurotropic mechanisms of SARS-CoV-2 are yet to be established. SARSCoV-2 may affect CNS through two direct mechanisms (hematogenous dissemination or neuronal retrograde dissemination) or via indirect routes. The underlying mechanisms require further elucidation in the future.

There are 2 case series specifically describing neurological manifestations and complications in COVID-19 patients. The first is a retrospective case series on neurological manifestation from China by Mao et al. ${ }^{5}$ This study done on 214 patients, showed neurological manifestations in $34 \%$ in the form of acute cerebrovascular diseases (5), impaired consciousness (13) and skeletal muscle injury (17).

The second article is a prospective case series of 58 patients from France. ${ }^{7}$ This study reported neurological findings in the form of encephalopathy, prominent agitation, confusion, and corticospinal tract signs.

Here we are reporting three COVID 19 positive cases having neurological manifestations.

The first case described here is a case of bilateral symmetrical sensory motor axonal polyneuropathy seen in a patient with COVID 19 infection. Presence of $\mathrm{IgG}$ and $\operatorname{IgM}$ antibodies against SARS CoV2 in CSF and serum could suggest a possibility COVID 19 associated neuropathy due to immune mediated injury.

The second case described was diagnosed as a case of Guillian Barre syndrome on the basis of classical clinical presentation and NCV findings. Our 2 nd patient had mild fever \& dry cough started on the same day of weakness, however X ray chest \& HRCT chest was suggestive of atypical pneumonia and patient was COVID 19 positive by CBNAAT and also antibodies were detected in serum as well as CSF.

The third case described was of Guillian Barre syndrome with COVID 19 RTPCR positive in CSF\& absence of antibodies with near normal recovery after 5 cycles of Plasmapheresis.

Following are the case definitions suggested for association of COVID 19 with neurological disease. $^{8} \quad$ For Acute disseminated encephalomyelitis associated with SARS-CoV-2 infection, Guillain-Barré syndrome and other acute neuropathies associated with SARS-CoV-2 infection

\section{Probable Association}

(1) Neurological disease onset within 6 weeks of acute infection; and (2) either SARS-CoV-2 RNA detected in any sample or antibody evidence of acute SARS-CoV-2 infection; and (3) no evidence of other commonly associated causes

\section{Possible Association}

(1) Neurological disease onset within 6 weeks of acute infection; and (2) either SARS-CoV-2 RNA detected in any sample or antibody evidence of acute SARS-CoV-2 infection; and (3) evidence of other commonly associated causes

These include infection with one of Campylobacter jejuni, Mycoplasma pneumoniae, Cytomegalovirus, Epstein-Barr virus, hepatitis E virus, Zika virus, or HIV; or vaccination in the last 6 weeks. Associated causes might differ depending on geographical location. 
To date, 19 patients (six female) with GuillainBarré syndrome or its variants and COVID-19 have been reported. ${ }^{9,10}$

\section{Conclusion}

Although COVID-19 preferentially affects the respiratory and cardiovascular system, many patients are also likely to have neurological symptoms and complications so high index of suspicion is required during this COVID 19 epidemic. Patients coming with neurological manifestations should suspect severe acute respiratory syndrome coronavirus 2 infections as a differential diagnosis to avoid delayed diagnosis.

Also Recognition of neurological disease associated with SARS-CoV-2 in patients whose respiratory infection is mild or asymptomatic might prove challenging, especially if the primary COVID-19 illness occurred weeks earlier.

\section{References}

1. Guan WJ, Ni ZY, Hu Y, Liang WH, Ou CQ, He JX, Liu L, Shan H, Lei CL, Hui DS, Du B. Clinical characteristics of coronavirus disease 2019 in China. N Engl J Med. 2020;382(18):1708-20

2. Huang C, Wang Y, Li X, Ren L, Zhao J, $\mathrm{Hu} \mathrm{Y}$, et al. Clinical features of patients infected with 2019 novel coronavirus in Wuhan, China. Lancet. 2020;395 (10223): 497-506.

3. Bhatraju PK, Ghassemieh BJ, Nichols M, Kim R, Jerome KR, Nalla AK, Greninger AL, Pipavath S, Wurfel MM, Evans L, Kritek PA. Covid-19 in critically ill patients in the Seattle region-case series. N Engl J Med. 2020;382(21):2012-22

4. Nath A. Neurologic complications of coronavirus infections. Neurology. 2020;94(19):809-10

5. Mao L, Jin H, Wang M, Hu Y, Chen $\mathrm{S}, \mathrm{He}$ Q, Chang J, Hong C, Zhou Y, Wang D, Miao X. Neurologic manifestations of hospitalized patients with coronavirus disease 2019 in Wuhan, China. JAMA Neurol. 2020;77(6):683-90

6. Imran Ahmad, Farooq Azam Rathore. Neurological manifestations and complications of COVID-19: A literature review, Journal of Clinical Neuroscience, 2020; 77: 8-12

7. J. Helms, S. Kremer, H. Merdji, R. ClereJehl, M. Schenck, C. Kummerlen, etal.Neu rologic Features in Severe SARS-CoV-2 Infection. N Engl J Med (2020), 10.1056/NEJMc2008597

8. Mark A Ellul, Laura Benjamin, Bhateshwar Singh, Suzannah Lant, et al. Neurological associations of COVID-19. The Lancet Neurology. 2020;19(9): 767783

9. Abdelnour L, Eltahir Abdalla M, Babiker S. COVID 19 infection presenting as motor peripheral neuropathy. J Formos Med Assoc 2020; 119: 1119-20.

10. Alberti P, Beretta S, Piatti M, et al. Guillain-Barré syndrome related to COVID-19 infection. Neurol Neuroimmunol Neuroinflammation 2020; 7: e741. 